\title{
Aplikasi Sistem Pakar Diagnosa Penyakit Anjing Berbasis Facebook Messenger
}

\author{
Veronica Ambassador Flores ${ }^{1}$, Lina Wati ${ }^{2}$ \\ Submission: 11-02-2020, Accepted: 28-06-2020
}

\begin{abstract}
An Expert System of Disease Diagnosis in Dogs Based on Facebook Messenger was a useful application to provide an initial diagnosis of the diseases based on the symptoms given by the users. The application uses the Facebook Messenger-based on Natural Language Processing (NLP) method to allow users to easily and comfortably interacting with the app. Diagnosis was obtained by identifying the pattern, and classifying the pattern. The method used in the pattern identification process is N-gram, this method was a matching pattern method where the number of words or character pattern that would be match could be adjusted. The method used to classify a disease is a Matching Template, this method worked by matching the template pattern with the test pattern to find the similarities between the patterns. The study concluded that the application of an expert systems using the $\mathrm{N}$-gram method and the Matching Template had an accurate diagnosis rate of $80 \%$.
\end{abstract}

Intisari-Menjaga kesehatan hewan khususnya anjing merupakan hal yang penting, hal ini dikarenakan interaksi yang terjadi antara manusia dan anjing peliharaan sangatlah dekat. Penelitian ini membangun sistem pakar diagnosa penyakit anjing yang berguna untuk memberikan diagnosa awal terhadap suatu penyakit berdasarkan gejala yang diberikan oleh pengguna melalui Facebook Messenger. Diagnosa didapatkan dengan mengidentifikasi pola, dan mengklasifikaskan pola tersebut. Metode yang digunakan untuk mengidentifikasi pola adalah $\mathrm{N}$-gram, metode ini mencocokkan kata atau karakter terhadap sebuah pola dimana jumlah karakter yang dicocokkan bisa disesuaikan. Metode yang digunakan untuk mengklasifikasikan penyakit adalah Template Matching, metode ini melakukan pencocokan antara template pola dengan pola uji untuk mencari nilai kesamaan antara pola tersebut. Penelitian ini menyimpulkan bahwa aplikasi sistem pakar dengan menggunakan metode $\mathrm{N}$-gram dan Template Matching dapat bekerja dengan baik dengan tingkat akurasi sebesar $80 \%$.

Kata Kunci-Sistem Pakar, Natural Language Processing (NLP), N-gram, Pattern Matching, Facebook Messenger

\section{Pendahuluan}

Memelihara hewan merupakan hobi bagi beberapa orang,

${ }^{1}$ Mahasiswa, Magister Teknik Elektro Universitas Udayana Gedung Pascasarjana Universitas Udayana, Jl. PB Sudirman Denpasar-Bali 80232 (tlp: 0361-555225; fax: 0361-432198; email: veronicaambassador@gmail.com)

${ }^{2}$ Dosen, Magister Teknik Elektro Universitas Udayana Gedung Pascasarjana Universitas Udayana, Jl. PB Sudirman Denpasar-Bali 80232 (tlp: 0361-555225; fax: 0361-4321982; email:linawati@unud.ac.id) salah satu hewan peliharaan yang paling populer adalah anjing. Manusia gemar memelihara anjing dikarenakan anjing bisa dimanfaatkan untuk membantu manusia dalam sisi keamanan, seperti menjaga rumah, mencari narkoba, bahan peledak, dan mengamati orang-orang yang dianggap mencurigakan [1].

Beberapa penelitian membahas mengenai keterkaitan kelangsungan hidup seseorang yang akan lebih panjang jika mereka tinggal bersama anjing di dalam rumahnya [2], salah satu penyebabnya adalah karena anjing dapat mengurangi tingkat stres pada manusia. Hormon oxytocin, dopamine, dan endorphins akan meningkat saat manusia melakukan interaksi bersama anjing, seperti saat bermain bersama, atau saat mengelus bulu anjing [3].

Menjaga kesehatan hewan khususnya anjing dirasa perlu, mengingat begitu dekatnya interaksi yang terjadi antara manusia dan anjing peliharaannya. Beberapa orang terkadang kurang peka terhadap penyakit yang dialami oleh peliharaanya, hal ini dapat dikarenakan kurangnya waktu dan biaya untuk melakukan konsultasi dengan pakar atau dokter hewan. Pengguna dapat lebih menghemat waktu dan biaya dengan melakukan semuanya melalui aplikasi Instant Messaging yang sudah terpasang di smartphone tiap orang. Instant Messaging sendiri merupakan aplikasi komunikasi yang bersifat realtime [4], dimana penggunanya dapat dengan bebas saling mengirimkan pesan berupa teks, gambar atau video. Menurut survei yang dilakukan oleh APJII pada tahun 2018, alasan utama mengapa orang Indonesia menggunakan Internet adalah untuk melakukan komunikasi melalui pesan instan di Internet, hal ini menunjukkan bahwa penggunaan Instant Messaging sudah menjadi gaya hidup tiap orang di Indonesia. Hasil survei juga menunjukkan bahwa Facebook merupakan konten yang paling sering dikunjungi oleh orang Indonesia [5]. Facebook sendiri memiliki fitur untuk saling berkirim pesan antar penggunanya, dimana fitur ini dikemas dalam aplikasi ketiga yang bernama Facebook Messenger. Penggunaan Instant Messaging seperti Facebook Messenger membuat pengguna akan lebih nyaman untuk melakukan komunikasi dengan menggunakan bahasa sehari-hari. Natural Language Processing (NLP) merupakan suatu kemampuan yang dapat mengenali bahasa sehari-hari yang digunakan manusia baik berupa teks maupun suara sehingga dapat dimengerti oleh komputer [6]. Penggunaan bahasa manusia dalam sebuah teks tentu dapat menimbulkan kesalahan tulis pada teks tersebut. Metode $\mathrm{N}$-gram merupakan metode pencocokan pola yang dapat mengenali suatu teks bahkan dengan kesalahan tulis sekalipun [7]. Pola yang cocok akan diklasifikasikan sehingga dapat menghasilkan suatu keputusan, salah satu metode klasifikasi yang dapat dipakai adalah Template Matching. Template Matching merupakan sebuah algoritma yang biasa digunakan dalam melakukan pencocokan citra binary,

Veronica Ambassador Flores: Aplikasi Sistem Pakar Diagnosa... 
algoritma metode ini membutuhkan data latih atau referensi data beserta hasil diagnosanya [8].

Penelitian [9] menggunakan sistem pakar untuk menangani keadaan darurat yang sering terjadi. Penelitian ini memanfaatkan sistem pakar untuk memberikan solusi terhadap keadaan atau situasi darurat yang terjadi, seperti kecelakaan atau serangan terroris.

Penelitian [10] membuat aplikasi BDES (Blood Disease Expert Sistem) untuk menentukan penyakit darah berdasarkan 13 pertanyaan mengenai kondisi darah tiap orang. Aplikasi ini dapat diterapkan di rumah sakit maupun diterapkan bagi media pembelajaran mahasiswa kedokteran. Penelitian ini membuktikan bahwa penerapan aplikasi BDES dapat menghemat waktu diagnosa dengan kinerja yang baik.

Penelitian [11] membuat sebuah sistem pakar untuk mendiagnosa penyakit kulit yang disebabkan oleh infeksi jamur berdasarkan data gejala yang telah disimpan sebagai basis pengetahuan. Penelitian ini menyatakan bahwa sistem pakar dapat dijadikan tahapan awal untuk mendiagnosa suatu penyakit berdasarkan gejala tertentu sebelum pasien melakukan konsultasi ke dokter.

Penelitian [12] membahas literatur-literatur mengenai Natural Language Processing. Penelitian ini menyatakan bahwa Natural Language Processing dapat membuat komputer mengerti bahasa manusia agar dapat mengerjakan berbagai tugas yang biasa dikerjakan oleh manusia.

Penelitian [13] membuat sistem pendeteksi bahasa dengan menggunakan metode $\mathrm{N}$-gram, hasil dari penelitian ini mengungkapkan bahwa $\mathrm{N}$-gram menunjukkan kinerja yang sangat baik dalam melakukan pencocokan pola pada sistem pendeteksi bahasa.

Penelitian [14] membuat sebuah sistem untuk melakukan pemeriksaan terhadap ejaan dalam Bahasa Vietnam. Penelitian ini membuktikan bahwa metode $\mathrm{N}$-gram dapat bekerja dengan baik dalam memperbaiki ejaan yang salah dengan performa yang baik.

Penelitian [8] menyimpulkan bahwa metode Template Matching merupakan pendekatan yang akurat untuk mengenali pola tulisan bahasa Jawa menggunakan Optical Character Recognition (OCR) dengan nilai akurasi sebesar $93.44 \%$ dan nilai error sebesar $6.56 \%$.

Berdasarkan latar belakang tersebut, maka tujuan utama dari penelitian ini yaitu merancang sebuah sistem pakar untuk mendiagnosa penyakit yang ada pada spesies anjing dengan pendekatan Natural Language Processing berbasis Facebook Messenger.

\section{LANDASAN TEORI}

Teori pendukung yang menjadi landasan dalam melakukan penelitian ini antara lain:

\section{A. Sistem Pakar}

Sistem pakar merupakan sistem yang berguna untuk mendokumentasikan data pengalaman, keahlian, dan ilmu pengetahuan dari seorang pakar sebelum pakar tersebut meninggal dunia atau pensiun dari pekerjaannya. Penelitian mengenai sistem kepakaran sudah dilakukan sejak tahun 1996 - sekarang, sistem kepakaran ini mencangkup data militer, kesehatan, manajemen, dan lain sebagainya [15]. Sistem pakar menyediakan fasilitas bagi pengguna agar dapat melakukan interaksi dengan komputer untuk menyelesaikan suatu masalah, dimana pengguna nantinya dapat memberikan data berupa gejala penyakit atau keluhan yang dialami [16].

\section{B. Text Mining}

Text Mining berguna untuk mencari pola, informasi atau pengetahuan yang dianggap menarik dari sekumpulan data yang berupa teks dengan jumlah rangkaian kata yang sangat besar [17] [18]. Proses Text Mining diawali dengan melakukan text pre-processing, dimana semua karakter pada sebuah teks diubah guna membuang data yang dianggap tidak perlu dan mengurangi adanya ketidaksempurnaan data [19]. Proses dalam text pre-processing dibagi kedalam beberapa tahapan, antara lain sebagai berikut:

- Case folding, pada tahap ini terdapat dua pemprosesan, pertama mengubah teks yang sudah di parsing menjadi huruf kecil, kedua menghilangkan semua karakter angka yang terdapat pada teks.

- Tokenizing, tahapan ini memisahkan teks utuh menjadi potongan-potongan kata.

- Filtering adalah proses untuk menghapus atau menghilangkan kata yang dianggap tidak perlu, dimana kata ini termasuk kedalam jenis stopword. Penelitian ini memasukkan semua kata yang tidak berhubungan dengan pola gejala sebagai stopword, agar nantinya kata tersebut tidak mempengaruhi hasil pencocokan pada pola.

- Stemming adalah proses untuk mengembalikan sebuah kata kembali ke kata dasarnya.

\section{N-Gram}

$N$-gram merupakan salah satu metode yang digunakan untuk melakukan pencocokan pola, dimana $N$-gram akan mengurutkan kata yang telah di parsing dari sebuah teks [7]. Metode pencocokan dengan $\mathrm{N}$-gram dibagi menjadi dua jenis, yaitu pencocokan per karakter, dan pencocokan per kata. Penerapan metode $N$-gram dapat menggunakan berbagai cara seperti unigram $(\mathrm{n}=1)$, bigram $(\mathrm{n}=2)$, trigram $(\mathrm{n}=3)$, dan seterusnya [20].

TABEL I

CONTOH N-GRAM

\begin{tabular}{|c|c|c|c|c|}
\hline \multirow{2}{*}{ No } & \multirow{2}{*}{ Jenis } & \multicolumn{3}{|c|}{ Teks = Tidak nafsu makan } \\
\hline & & Unigram & Bigram & Trigram \\
\hline 1 & $\begin{array}{c}\text { Per- } \\
\text { karakter }\end{array}$ & $\begin{array}{l}\text { t,i,d,a,k, } \\
\text { n,a,f,s,u, } \\
\text { m,a,k,a, } \\
\text { n }\end{array}$ & $\begin{array}{l}\text { t, ti, id, da, } \\
\text { ak, k, n, na, } \\
\text { af, fs, su, } \\
\text { um, ma, ak, } \\
\text { ka, an, n }\end{array}$ & $\begin{array}{l}\text { ti, tid, ida, dak, } \\
\text { ak, na, naf, } \\
\text { afs, fsu, su, } \\
\text { ma, mak, aka, } \\
\text { kan, an }\end{array}$ \\
\hline 2 & Per-kata & $\begin{array}{l}\text { tidak, } \\
\text { nafsu, } \\
\text { makan }\end{array}$ & $\begin{array}{l}\text { tidak nafsu, } \\
\text { nafsu makan }\end{array}$ & $\begin{array}{l}\text { tidak nafsu } \\
\text { makan }\end{array}$ \\
\hline
\end{tabular}

\section{Template Matching}

Template Matching merupakan algoritma sederhana yang biasa digunakan dalam pengenalan citra digital. Algoritma Template Matching bekerja dengan melakukan perhitungan jarak kecocokan antara template pola yang ada dengan pola uji sehingga mendapatkan nilai kemiripan dari kedua pola 
tersebut [21] [22]. Perhitungan kemiripan antara template pola dengan pola uji dapat diukur dengan nilai error terkecil antara keduanya. Persamaan 1 dapat digunakan untuk mengukur nilai error pada template pola dan pola uji.

$$
d(q, p)=\sum_{\mathrm{i}=1}^{n}\left(p_{i}-q_{i}\right)^{2}
$$

Keterangan :

$d=$ nilai error dari kedua pola

$q=$ biner dari template pola

$p=$ biner dari pola uji

Template dengan perhitungan nilai error terkecil menandakan bahwa template tersebut yang paling sesuai dengan pola uji.

\section{E. Instant Messaging}

Instant Messaging adalah aplikasi komunikasi peer to peer yang dapat membuat pengunanya dapat saling bertukar pesan secara online. Instant Messaging mengharuskan pengguna untuk mendaftar terlebih dahulu di platform mereka, setelah itu barulah pengguna dapat berkomunikasi dengan pengguna lainnya [23].

\section{F. Facebook Messenger}

Aplikasi Facebook Messenger merupakan aplikasi media sosial terpopuler nomor dua setelah Whatsapp, total pengguna aktif Facebook Messenger mencapai 397 M akun [24]. Facebook Messenger telah terintegrasi dengan aplikasi Facebook, sehingga pengguna yang ingin bertukar pesan dengan pengguna Facebook lainnya harus melakukan instalasi aplikasi Facebook Messenger secara terpisah. Facebook juga merupakan salah satu media sosial yang dapat dijadikan sebagai sarana untuk menyampaikan suatu opini [25]. Fitur yang dimiliki Facebook Messenger yaitu pengiriman pesan melalui teks atau video, grup, panggilan suara, photo sharing, video sharing, dan document sharing [23].

\section{Metodologi Penelitian}

Data yang digunakan dalam penelitian ini dikumpulkan dengan melakukan studi pustaka untuk mendapatkan informasi mengenai penyakit dan gejala yang menyertai penyakit tersebut serta metode yang akan dipakai untuk merealisasikan sistem pakar ini yang meliputi metode identifikasi pola menggunakan $N$-gram dan metode klasifikasi Template Matching.

\section{A. Data Penelitian}

Data yang digunakan dalam penelitian ini didapat dari berbagai jurnal dan website yang membahas mengenai penyakit anjing.

1) Data Penyakit Anjing: Data ini berisikan daftar penyakit yang biasanya menyerang spesies anjing, baik yang disebabkan oleh virus, bakteri, atau pola makan yang salah.

Veronica Ambassador Flores: Aplikasi Sistem Pakar Diagnosa...
Tabel 2 menampilkan daftar nama-nama penyakit yang biasa menyerang anjing [26].

TABEL II

DATA PENYAKIT ANJING (P)

\begin{tabular}{|c|l|}
\hline Kode & \multicolumn{1}{|c|}{ Nama Penyakit } \\
\hline P01 & Canine Distemper (Virus Distemper) \\
\hline P02 & Canine Influenza (Flu) \\
\hline P03 & $\begin{array}{l}\text { Canine Parvovirus (Muntaber/Virus } \\
\text { Parvo) }\end{array}$ \\
\hline P04 & Parasit (kutu dan kudis) \\
\hline P05 & Infeksi Jamur \\
\hline P06 & Heartworms (Cacing Jantung) \\
\hline P07 & Heatstroke (Kepanasan) \\
\hline P08 & Parasit Usus \\
\hline P09 & Kennel Cough (Batuk) \\
\hline P10 & Leptospirosis \\
\hline P11 & Rabies \\
\hline P12 & Ringworm (Jamur Kulit) \\
\hline
\end{tabular}

2) Data Gejala Penyakit Anjing: Data gejala terdiri dari macam-macam gejala yang menjadi faktor penentu untuk menentukan suatu penyakit. Tabel 3 menunjukkan daftar gejala dari penyakit yang ada pada Tabel 2 .

TABEL III

DAta GeJala Penyakit (G)

\begin{tabular}{|l|l|}
\hline Kode & \multicolumn{1}{|c|}{ Gejala Penyakit } \\
\hline G01 & Mata Berair \\
\hline G02 & Demam \\
\hline G03 & Hidung Berair \\
\hline G04 & Batuk \\
\hline G05 & Muntah \\
\hline G06 & Diare \\
\hline G07 & Kejang \\
\hline G08 & Kelumpuhan \\
\hline G09 & Diare Berdarah \\
\hline G10 & Kehilangan Nafsu Makan \\
\hline G11 & Kulit Gatal \\
\hline G12 & Benjolan Merah pada Kulit \\
\hline G13 & Lesu \\
\hline G14 & Kesulitan Bernafas \\
\hline G15 & Air Liur yang Berlebih \\
\hline G16 & Cemas \\
\hline G17 & Lemah \\
\hline G18 & Warna Gusi Abnormal (Merah \\
\hline G19 & Belap atau Ungu) \\
\hline G20 & Agresif \\
\hline G21 & Bulu Rontok \\
\hline
\end{tabular}

3) Data Keputusan Penyakit: Data keputusan terdiri dari keterkaitan antara jenis penyakit beserta gejala yang menyertai penyakit tersebut. Tabel 4 menampilkan aturan diagnosa dari data penyakit dan gejala, sehingga dapat menghasilkan keputusan akhir yang akurat.

p-ISSN:1693 - 2951; e-ISSN: 2503-2372 
TABEL IV

DATA KEPUTUSAN

\begin{tabular}{|c|c|c|c|c|c|c|c|c|c|c|c|c|}
\hline $\mathbf{P}$ & $\begin{array}{l}\mathbf{P} \\
01\end{array}$ & $\begin{array}{c}\mathbf{P} \\
\mathbf{0 2}\end{array}$ & $\begin{array}{c}\mathbf{P} \\
\mathbf{0 3}\end{array}$ & $\begin{array}{c}\text { P } \\
04\end{array}$ & $\begin{array}{l} \\
05\end{array}$ & $\begin{array}{l}P \\
06\end{array}$ & $\begin{array}{c}\mathbf{P} \\
\mathbf{0 7}\end{array}$ & $\begin{array}{c}\mathbf{P} \\
08\end{array}$ & $\begin{array}{c}\mathbf{P} \\
\mathbf{0 9}\end{array}$ & $\begin{array}{c}\mathbf{P} \\
\mathbf{1 0}\end{array}$ & $\begin{array}{c}P \\
\mathbf{P}\end{array}$ & $\begin{array}{c}P \\
12\end{array}$ \\
\hline G & $\mathbf{A}$ & B & $\mathbf{C}$ & D & $\mathbf{E}$ & $\mathbf{F}$ & $\mathbf{G}$ & $\mathbf{H}$ & I & $\mathbf{J}$ & $\mathbf{K}$ & $\mathbf{L}$ \\
\hline $\begin{array}{c}\mathbf{G} \\
\mathbf{0 1}\end{array}$ & $\sqrt{ }$ & & & & & & & & & & & \\
\hline $\begin{array}{c}\mathbf{G} \\
\mathbf{0 2}\end{array}$ & $\sqrt{ }$ & $\sqrt{ }$ & $\sqrt{ }$ & & $\sqrt{ }$ & & & & & $\sqrt{ }$ & $\sqrt{ }$ & \\
\hline $\begin{array}{c}\mathbf{G} \\
\mathbf{0 3}\end{array}$ & $\sqrt{ }$ & $\sqrt{ }$ & & & & & & & $\sqrt{ }$ & & & \\
\hline $\begin{array}{c}\text { G } \\
\mathbf{0 4}\end{array}$ & $\sqrt{ }$ & $\sqrt{ }$ & & & $\sqrt{ }$ & $\sqrt{ }$ & & & $\sqrt{ }$ & & & \\
\hline $\begin{array}{c}\text { G } \\
05\end{array}$ & $\sqrt{ }$ & & $\sqrt{ }$ & & & & & & & $\sqrt{ }$ & & \\
\hline $\begin{array}{c}\mathbf{G} \\
06\end{array}$ & $\sqrt{ }$ & & & & & & & $\sqrt{ }$ & & & & \\
\hline $\begin{array}{c}\mathbf{G} \\
\mathbf{0 7}\end{array}$ & $\sqrt{ }$ & & & & & & & & & & & \\
\hline $\begin{array}{c}\mathbf{G} \\
\mathbf{0 8}\end{array}$ & $\sqrt{ }$ & & & & & & & & & & & \\
\hline $\begin{array}{c}\text { G } \\
09\end{array}$ & & & $\sqrt{ }$ & & & & & & & & & \\
\hline $\begin{array}{c}\mathbf{G} \\
\mathbf{1 0}\end{array}$ & & & $\sqrt{ }$ & & & & & & & & $\sqrt{ }$ & \\
\hline $\begin{array}{c}\mathbf{G} \\
\mathbf{1 1}\end{array}$ & & & & $\sqrt{ }$ & & & & & & & & $\sqrt{ }$ \\
\hline $\begin{array}{c}\mathbf{G} \\
12\end{array}$ & & & & $\sqrt{ }$ & & & & & & & & \\
\hline $\begin{array}{c}\mathbf{G} \\
\mathbf{1 3}\end{array}$ & & & & & $\sqrt{ }$ & $\sqrt{ }$ & & & & $\sqrt{ }$ & & \\
\hline $\begin{array}{c}\mathrm{G} \\
14\end{array}$ & & & & & & $\sqrt{ }$ & & & & & & \\
\hline $\begin{array}{c}\mathbf{G} \\
\mathbf{1 5}\end{array}$ & & & & & & & $\sqrt{ }$ & & & & $\sqrt{ }$ & \\
\hline $\begin{array}{c}G \\
16\end{array}$ & & & & & & & $\sqrt{ }$ & & & & $\sqrt{ }$ & \\
\hline $\begin{array}{l}\mathbf{G} \\
\mathbf{1 7}\end{array}$ & & & & & & & $\sqrt{ }$ & & & $\sqrt{ }$ & & \\
\hline $\begin{array}{c}\mathrm{G} \\
\mathbf{1 8}\end{array}$ & & & & & & & $\sqrt{ }$ & & & & & \\
\hline $\begin{array}{c}\mathbf{G} \\
\mathbf{1 9}\end{array}$ & & & & & & & & $\sqrt{ }$ & & & & \\
\hline $\begin{array}{c}\mathbf{G} \\
20\end{array}$ & & & & & & & & & & & $\sqrt{ }$ & \\
\hline $\begin{array}{c}\mathbf{G} \\
21 \\
\end{array}$ & & & & & & & & & & & & $\sqrt{ }$ \\
\hline
\end{tabular}

\section{B. Gambaran Umum Sistem}

Sistem pakar dapat mendiagnosa penyakit anjing melalui gejala yang diberikan oleh pengguna. Secara umum sistem ini bekerja dengan mengambil pesan yang dikirimkan oleh pengguna melalui Facebook Messenger. Pesan diprores menjadi kumpulan kata sehingga dapat dilakukan proses pencocokkan terhadap pola gejala yang sudah tersimpan. Pola yang terbentuk dari hasil pencocokkan akan diklasifikasikan kedalam penyakit yang memiliki gejala yang serupa dengan pola yang telah diidentifikasi. Diagnosa penyakit didapatkan melalui prroses klasifikasi kemudian dikirim kembali kepada pengguna sebagai respon dari pertanyaan yang dikirimlan melalui Facebook Messenger. Detail proses dari cara kerja sistem pakar ini ditampilkan pada Gambar 1. Pesan di parsing dan dicocokan dengan ola geala menggnakan Metode Ngram, kesimulan didapat dengan mengklasifikasikan gejala dengan ola enyakli.

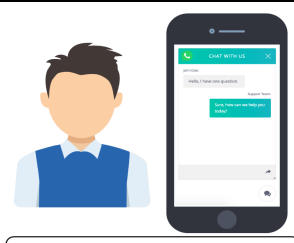

Pengguna

mengirimkan gejala penyakit yang dialami

oleh anjing melalui

Facebook Messenger

Respon

Respon

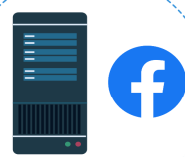

Pengguna

mengirimkan gejala

penyakit yang dialami

oleh anjing melalui

Facebook Messenger
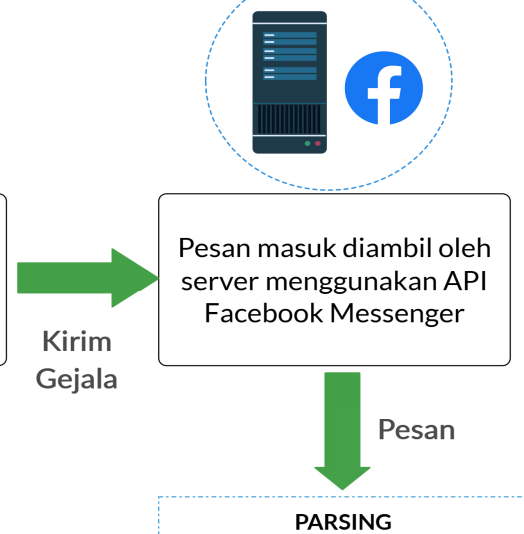

TEXT PRE-PROCESSING

SIMILARIY MATCHING (NGRAM)

KLASIFIKASI

Pesan di parsing dan dicocokan dengan pola gejala menggunakan Metode Ngram, kesimpulan didapat dengan mengklasifikasikan gejala dengan pola penyakit.

Gambar 1: Cara Kerja Aplikasi Sistem Pakar Diagnosa Penyakit Anjing

Ilustrasi cara kerja Aplikasi Sistem Pakar Diagnosa Penyakit Anjing terdiri dari beberapa tahapan, yaitu :

1) Tahap 1: Pengguna mengirimkan pesan melalui Facebook Messenger : "Anjing saya gtal2 badannya sampai luka"

2) Tahap 2: Pesan yang dikirimkan oleh pengguna di parsing menggunakan API Facebook Messenger menggunakan aplikasi Python.

3) Tahap 3: Text Pre-processing.

- Case folding, anjing saya gtal badannya sampai luka

- Tokenizing, [anjing], [saya], [gtal], [badannya], [sampai], [luka]

- Filtering, [gtal]

- Stemming, [gtal]

4) Tahap 4: Similarity Matching menggunakan metode $\mathrm{N}$ gram tipe Trigram. Teks = gtal, jika dicocokkan dengan pola gejala maka hasilnya akan seperti Tabel 5.

TABEL V

Data Pola Gejala

\begin{tabular}{|c|l|l|c|}
\hline Kode & \multicolumn{1}{|c|}{ Gejala } & \multicolumn{1}{|c|}{ Pola Gejala } & Bobot \\
\hline G01 & Mata Berair & mata & 0.0 \\
\hline G02 & Demam & demam panas & 0.0 \\
\hline G03 & $\begin{array}{l}\text { Hidung } \\
\text { Berair }\end{array}$ & $\begin{array}{l}\text { hidung meler } \\
\text { bersin }\end{array}$ & 0.0 \\
\hline G04 & Batuk & batuk & 0.0 \\
\hline G05 & Muntah & muntah & 0.0 \\
\hline G06 & Diare & diare & 0.0 \\
\hline G07 & Kejang & kejang & 0.0 \\
\hline G08 & Kelumpuhan & lumpuh & 0.0 \\
\hline
\end{tabular}

Veronica Ambassador Flores: Aplikasi Sistem Pakar Diagnosa... 


\begin{tabular}{|c|l|l|c|}
\hline Kode & \multicolumn{1}{|c|}{ Gejala } & \multicolumn{1}{c|}{$\begin{array}{c}\text { Pola } \\
\text { Gejala }\end{array}$} & Bobot \\
\hline 09 & Diare Berdarah & $\begin{array}{l}\text { tai berak } \\
\text { darah }\end{array}$ & 0.0 \\
\hline G10 & $\begin{array}{l}\text { Kehilangan Nafsu } \\
\text { Makan }\end{array}$ & $\begin{array}{l}\text { nafsu } \\
\text { makan }\end{array}$ & 0.0 \\
\hline G11 & Kulit Gatal & $\begin{array}{l}\text { gatal } \\
\text { garuk }\end{array}$ & $\mathbf{0 . 1 1 7 6 4 7 0 5}$ \\
\hline G12 & $\begin{array}{l}\text { Benjolan Merah } \\
\text { pada Kulit }\end{array}$ & $\begin{array}{l}\text { bintik } \\
\text { bentol kulit }\end{array}$ & 0.0 \\
\hline G13 & Lesu & lesu & 0.0 \\
\hline G14 & $\begin{array}{l}\text { Kesulitan } \\
\text { Bernafas }\end{array}$ & nafas & 0.0 \\
\hline G15 & $\begin{array}{l}\text { Air Liur yang } \\
\text { Berlebih }\end{array}$ & liur, busa & 0.0 \\
\hline G16 & Cemas & cemas & 0.0 \\
\hline G17 & Lemah & lemah & 0.0 \\
\hline G18 & $\begin{array}{l}\text { Warna Gusi } \\
\text { Abnormal (Merah } \\
\text { Gelap atau Ungu) }\end{array}$ & warna gusi & 0.0 \\
\hline G19 & Badan Kurus & kurus & 0.0 \\
\hline G20 & Agresif & $\begin{array}{l}\text { agresif } \\
\text { galak }\end{array}$ & 0.0 \\
\hline G21 & Bulu Rontok & bulu rontok & 0.0 \\
\hline
\end{tabular}

Perhitungan error yang mengacu pada (1) dapat dilihat pada Tabel 7.

TABEL VII

PERHITUNGAN ERROR

\begin{tabular}{|c|c|c|}
\hline Penyakit & Perhitungan Error & Hasil \\
\hline P01 & $\begin{array}{l}\left((0-1)^{2}\right)+\left((0-1)^{2}\right)+\left((0-1)^{2}\right)+\left((0-1)^{2}\right)+((0- \\
\left.1)^{2}\right)+\left((0-1)^{2}\right)+\left((0-1)^{2}\right)+\left((0-1)^{2}\right)+\left((0-0)^{2}\right)+((0- \\
\left.0)^{2}\right)+\left(\left((1-0)^{2}\right)+\left((0-0)^{2}\right)+\left((0-0)^{2}\right)+\left((0-0)^{2}\right)+((0-\right. \\
\left.0)^{2}\right)+\left((0-0)^{2}\right)+\left((0-0)^{2}\right)+\left((0-0)^{2}\right)+\left((0-0)^{2}\right)+((0- \\
\left.0)^{2}\right)+\left((0-0)^{2}\right)\end{array}$ & 9 \\
\hline $\mathrm{P} 02$ & $\begin{array}{l}\left((0-0)^{2}\right)+\left((0-1)^{2}\right)+\left((0-1)^{2}\right)+\left((0-1)^{2}\right)+((0- \\
\left.0)^{2}\right)+\left((0-0)^{2}\right)+\left((0-0)^{2}\right)+\left((0-0)^{2}\right)+\left((0-0)^{2}\right)+((0- \\
\left.0)^{2}\right)+\left(\left((1-0)^{2}\right)+\left((0-0)^{2}\right)+\left((0-0)^{2}\right)+\left((0-0)^{2}\right)+((0-\right. \\
\left.0)^{2}\right)+\left((0-0)^{2}\right)+\left((0-0)^{2}\right)+\left((0-0)^{2}\right)+\left((0-0)^{2}\right)+((0- \\
\left.0)^{2}\right)+\left((0-0)^{2}\right)\end{array}$ & 4 \\
\hline P03 & $\begin{array}{l}\left((0-0)^{2}\right)+\left((0-1)^{2}\right)+\left((0-0)^{2}\right)+\left((0-0)^{2}\right)+((0- \\
\left.1)^{2}\right)+\left((0-0)^{2}\right)+\left((0-0)^{2}\right)+\left((0-0)^{2}\right)+\left((0-1)^{2}\right)+((0- \\
\left.1)^{2}\right)+\left((1-0)^{2}\right)+\left((0-0)^{2}\right)+\left((0-0)^{2}\right)+\left((0-0)^{2}\right)+((0- \\
\left.0)^{2}\right)+\left(\left((0-0)^{2}\right)+\left((0-0)^{2}\right)+\left((0-0)^{2}\right)+\left((0-0)^{2}\right)+((0-\right. \\
\left.0)^{2}\right)+\left((0-0)^{2}\right)\end{array}$ & 5 \\
\hline P04 & $\begin{array}{l}\left((0-0)^{2}\right)+\left((0-0)^{2}\right)+\left((0-0)^{2}\right)+\left((0-0)^{2}\right)+((0- \\
\left.0)^{2}\right)+\left((0-0)^{2}\right)+\left((0-0)^{2}\right)+\left((0-0)^{2}\right)+\left((0-0)^{2}\right)+((0- \\
\left.0)^{2}\right)+\left((1-1)^{2}\right)+\left((0-1)^{2}\right)+\left((0-0)^{2}\right)+\left((0-0)^{2}\right)+((0- \\
\left.0)^{2}\right)+\left((0-0)^{2}\right)+\left((0-0)^{2}\right)+\left((0-0)^{2}\right)+\left((0-0)^{2}\right)+((0- \\
\left.0)^{2}\right)+\left((0-0)^{2}\right)\end{array}$ & 1 \\
\hline P05 & $\begin{array}{l}\left((0-0)^{2}\right)+\left((0-1)^{2}\right)+\left((0-0)^{2}\right)+\left((0-1)^{2}\right)+((0- \\
\left.0)^{2}\right)+\left((0-0)^{2}\right)+\left((0-0)^{2}\right)+\left((0-0)^{2}\right)+\left((0-0)^{2}\right)+((0- \\
\left.0)^{2}\right)+\left(\left((1-0)^{2}\right)+\left((0-0)^{2}\right)+\left((0-1)^{2}\right)+\left((0-0)^{2}\right)+((0-\right. \\
\left.0)^{2}\right)+\left((0-0)^{2}\right)+\left((0-0)^{2}\right)+\left((0-0)^{2}\right)+\left((0-0)^{2}\right)+((0- \\
\left.0)^{2}\right)+\left((0-0)^{2}\right)\end{array}$ & 4 \\
\hline P06 & $\begin{array}{l}\left((0-0)^{2}\right)+\left((0-0)^{2}\right)+\left((0-0)^{2}\right)+\left((0-1)^{2}\right)+((0- \\
\left.0)^{2}\right)+\left((0-0)^{2}\right)+\left((0-0)^{2}\right)+\left((0-0)^{2}\right)+\left((0-0)^{2}\right)+((0- \\
\left.0)^{2}\right)+\left(\left((1-0)^{2}\right)+\left((0-0)^{2}\right)+\left((0-1)^{2}\right)+\left((0-1)^{2}\right)+((0-\right. \\
\left.0)^{2}\right)+\left((0-0)^{2}\right)+\left((0-0)^{2}\right)+\left((0-0)^{2}\right)+\left((0-0)^{2}\right)+((0- \\
\left.0)^{2}\right)+\left((0-0)^{2}\right)\end{array}$ & 4 \\
\hline P07 & $\begin{array}{l}\left((0-0)^{2}\right)+\left((0-0)^{2}\right)+\left((0-0)^{2}\right)+\left((0-0)^{2}\right)+((0- \\
\left.0)^{2}\right)+\left((0-0)^{2}\right)+\left((0-0)^{2}\right)+\left((0-0)^{2}\right)+\left((0-0)^{2}\right)+((0- \\
\left.0)^{2}\right)+\left(\left((-0)^{2}\right)+\left((0-0)^{2}\right)+\left((0-0)^{2}\right)+\left((0-0)^{2}\right)+((0-\right. \\
\left.1)^{2}\right)+\left((0-1)^{2}\right)+\left((0-1)^{2}\right)+\left((0-1)^{2}\right)+\left((0-0)^{2}\right)+((0- \\
\left.0)^{2}\right)+\left(\left((0-0)^{2}\right)\right.\end{array}$ & 5 \\
\hline P08 & $\begin{array}{l}\left((0-0)^{2}\right)+\left((0-0)^{2}\right)+\left((0-0)^{2}\right)+\left((0-0)^{2}\right)+((0- \\
\left.0)^{2}\right)+\left((0-1)^{2}\right)+\left((0-0)^{2}\right)+\left((0-0)^{2}\right)+\left((0-0)^{2}\right)+((0- \\
\left.0)^{2}\right)+\left((1-0)^{2}\right)+\left((0-0)^{2}\right)+\left((0-0)^{2}\right)+\left((0-0)^{2}\right)+((0- \\
\left.0)^{2}\right)+\left((0-0)^{2}\right)+\left((0-0)^{2}\right)+\left((0-0)^{2}\right)+\left((0-1)^{2}\right)+((0- \\
\left.0)^{2}\right)+\left((0-0)^{2}\right)\end{array}$ & 3 \\
\hline P09 & $\begin{array}{l}\left((0-0)^{2}\right)+\left((0-0)^{2}\right)+\left((0-1)^{2}\right)+\left((0-1)^{2}\right)+((0- \\
\left.0)^{2}\right)+\left((0-0)^{2}\right)+\left((0-0)^{2}\right)+\left((0-0)^{2}\right)+\left((0-0)^{2}\right)+((0- \\
\left.0)^{2}\right)+\left((1-0)^{2}\right)+\left((0-0)^{2}\right)+\left((0-0)^{2}\right)+\left((0-0)^{2}\right)+((0- \\
\left.0)^{2}\right)+\left((0-0)^{2}\right)+\left((0-0)^{2}\right)+\left((0-0)^{2}\right)+\left((0-0)^{2}\right)+((0- \\
\left.0)^{2}\right)+\left((0-0)^{2}\right)\end{array}$ & 3 \\
\hline P10 & $\begin{array}{l}\left((0-0)^{2}\right)+\left((0-1)^{2}\right)+\left((0-0)^{2}\right)+\left((0-0)^{2}\right)+((0- \\
\left.1)^{2}\right)+\left((0-0)^{2}\right)+\left((0-0)^{2}\right)+\left((0-0)^{2}\right)+\left((0-0)^{2}\right)+((0- \\
\left.0)^{2}\right)+\left((1-0)^{2}\right)+\left((0-0)^{2}\right)+\left((0-1)^{2}\right)+\left((0-0)^{2}\right)+((0- \\
\left.0)^{2}\right)+\left(\left((0-0)^{2}\right)+\left((0-1)^{2}\right)+\left((0-0)^{2}\right)+\left((0-0)^{2}\right)+((0-\right. \\
\left.0)^{2}\right)+\left((0-0)^{2}\right)\end{array}$ & 5 \\
\hline P11 & $\begin{array}{l}\left((0-0)^{2}\right)+\left((0-1)^{2}\right)+\left((0-0)^{2}\right)+\left((0-0)^{2}\right)+((0- \\
\left.0)^{2}\right)+\left((0-0)^{2}\right)+\left((0-0)^{2}\right)+\left((0-0)^{2}\right)+\left((0-0)^{2}\right)+((0- \\
\left.1)^{2}\right)+\left(\left((1-0)^{2}\right)+\left((0-0)^{2}\right)+\left((0-0)^{2}\right)+\left((0-0)^{2}\right)+((0-\right. \\
\left.1)^{2}\right)+\left((0-1)^{2}\right)+\left((0-0)^{2}\right)+\left((0-0)^{2}\right)+\left((0-0)^{2}\right)+((0- \\
\left.1)^{2}\right)+\left(\left((0-0)^{2}\right)\right.\end{array}$ & 6 \\
\hline P12 & $\left((0-0)^{2}\right)+\left((0-0)^{2}\right)+\left((0-0)^{2}\right)+\left((0-0)^{2}\right)+((0-$ & 1 \\
\hline
\end{tabular}

Proses pencocokan dilakukan dengan membandingkan pola gejala dengan teks atau pesan dari pengguna. Kolom pola gejala adalah gejala-gejala yang sudah melewati proses text pre-processing serta sudah di tambahkan dengan padanan katanya. Pola Kulit Gatal dianggap pola gejala yang paling mendekati dengan yang disebutkan oleh pengguna dengan bobot kemiripan $\mathbf{0 . 1 1 7 6 4 7 0 5}$.

5) Tahap 5: Klasifikasi menggunakan metode Matching Template. Tabel 6 merupakan data dari pola penyakit dalam deretan angka biner.

TABEL VI

DATA PENYAKIT DALAM BINER

\begin{tabular}{|c|c|}
\hline Penyakit & Deretan Gejala dalam Biner \\
\hline P01 & 111111110000000000000 \\
\hline $\mathrm{P} 02$ & 011100000000000000000 \\
\hline $\mathrm{P} 03$ & 010010001100000000000 \\
\hline $\mathrm{P} 04$ & 000000000011000000000 \\
\hline P05 & 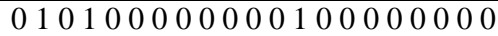 \\
\hline P06 & 000100000000110000000 \\
\hline $\mathrm{P} 07$ & 000000000000001111000 \\
\hline $\mathrm{P} 08$ & 000001000000000000100 \\
\hline P09 & 001100000000000000000 \\
\hline P10 & 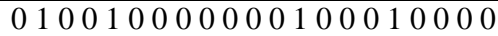 \\
\hline P11 & 010000000100001100010 \\
\hline P12 & 000000000010000000001 \\
\hline
\end{tabular}

Gejala yang dimasukkan oleh pengguna membenttuk data biner sebagai berikut:

000000000010000000000

p-ISSN:1693 - 2951; e-ISSN: 2503-2372

Veronica Ambassador Flores: Aplikasi Sistem Pakar Diagnosa... 


\begin{tabular}{|l|l|l|}
\hline 0$\left.)^{2}\right)+\left((0-0)^{2}\right)+\left((0-0)^{2}\right)+\left((0-0)^{2}\right)+\left((0-0)^{2}\right)+((0-$ \\
& $\left.0)^{2}\right)+\left((1-1)^{2}\right)+\left((0-0)^{2}\right)+\left((0-0)^{2}\right)+\left((0-0)^{2}\right)+((0-$ \\
& $\left.0)^{2}\right)+\left((0-0)^{2}\right)+\left((0-0)^{2}\right)+\left((0-0)^{2}\right)+\left((0-0)^{2}\right)+((0-$ & \\
$\left.0)^{2}\right)+\left((0-1)^{2}\right)$
\end{tabular}

Tabel 7 menunjukkan perhitungan nilai error dari tiap pola penyakit, nilai error yang paling kecil menjukkan bahwa pola penyakit tersebutlah yang paling sesuai dengan pola gejala yang dimasukkan oleh pengguna. Nilai terkecil ditunjukkan oleh gejala P04 dan P12, yang artinya gejala yang dimasukkan oleh pengguna mengarah ke penyakit Parasit (kutu dan kudis) dan Ringworm (Jamur Kulit).

6) Tahap 6: Diagnosa penyakit dikirimkan kepada pengguna melalui API Facebook Messenger dengan aplikasi Python.

\section{IV.PeMBAHASAN DAN ANALISIS Sistem}

Sistem pakar diagnosa penyakit anjing diharapkan dapat membantu pengguna untuk mendiagnosa penyakit umum yang biasa menyerang anjing berdasarkan gejala yang diberikan oleh pengguna. Keberhasilan sistem pakar ini dapat dilakukan dengan melakukan uji coba dari sisi antarmuka aplikasi dan akurasi dalam melakukan diagnosa penyakit.

\section{A. Implementasi}

Aplikasi Sistem Pakar Diagnosa Penyakit Anjing dibangun dengan dukungan aplikasi Facebook Messenger sebagai wadah untuk bertukar pesan. Tampilan aplikasi dapat dilihat pada Gambar 2.

Pengguna dapat melakukan konsultasi dengan mengirimkan pesan berupa gejala yang dialami oleh anjing mereka secara rinci kepada akun Hi Dog Care. Hasil diagnosa penyakit akan dikirimkan kepada pengguna lengkap dengan deskripsi dari penyakinya.

\section{B. Akurasi Identifikasi Pola}

Identifikasi pola diproses menggunakan metode Trigram yang telah diimplementasikan kedalam bentuk kode program. Tabel 8, menampilkan daftar identifikasi pola gejala penyakit anjing.

\section{$\leftarrow$ H Hi Dog Care}

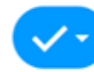

Anjing saya gatl2 badannya sampai luka

Terdapat 2 jenis diagnosa penyakit yang mungkin menyerang anjing anda

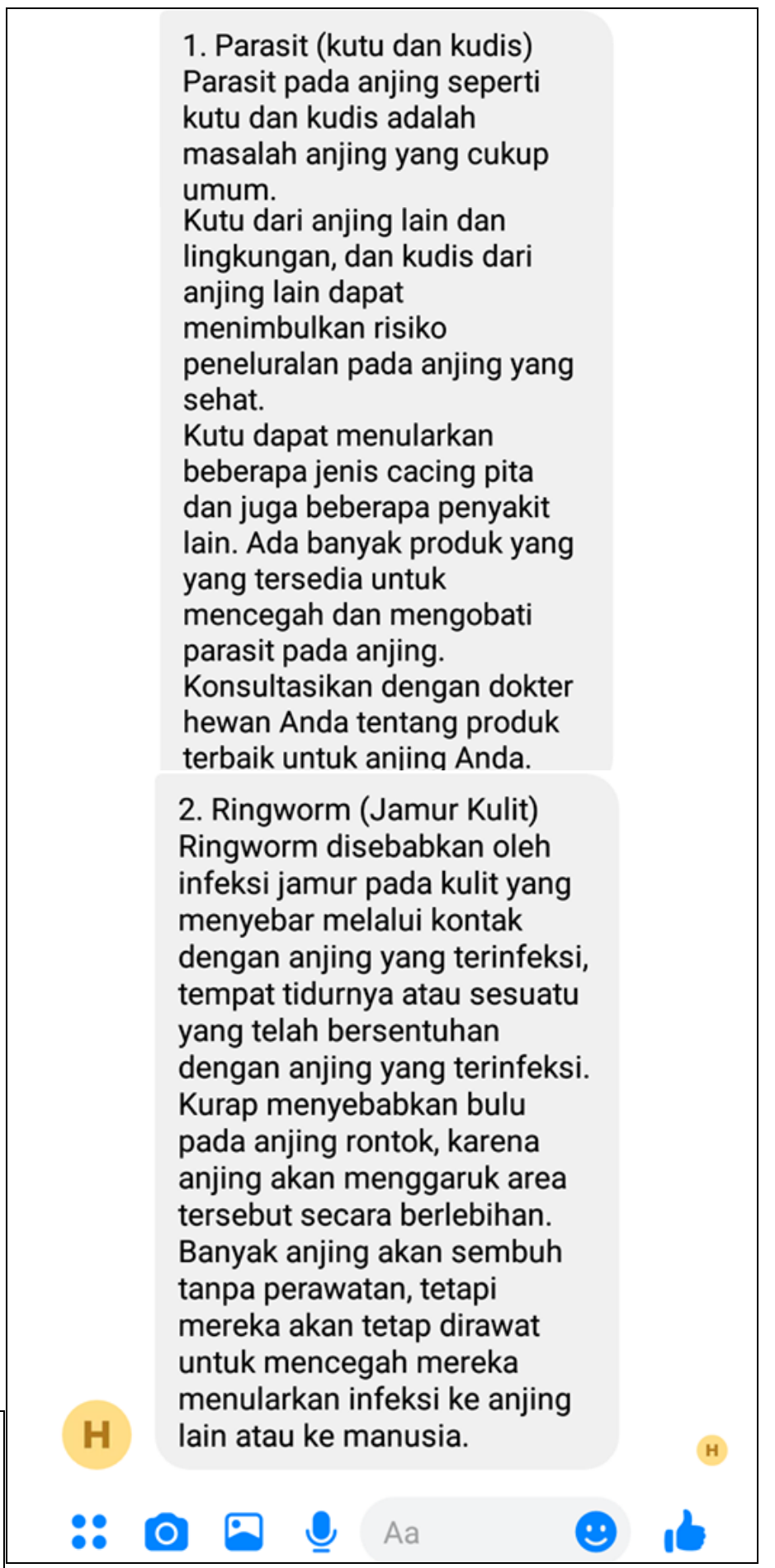

Gambar 2: Aplikasi Sistem Pakar Diagnosa Penyakit Anjing pada Facebook Messenger

TABEL VIII

UJI COBA IDENTIFIKASI POLA

\begin{tabular}{|c|c|c|c|}
\hline No & Pesan & Identifikasi Pola & Hasil \\
\hline 1 & $\begin{array}{l}\text { mohon infonya, anjing } \\
\text { saya gak mau makan, } \\
\text { muntah diare terus, dan } \\
\text { matanya berair. bisa } \\
\text { tolong dijawab }\end{array}$ & $\begin{array}{l}\text { - Mata Berair } \\
\text { - Muntah } \\
\text { - Diare } \\
\text { - Kehilangan Nafsu } \\
\text { Makan } \\
\end{array}$ & Sesuai \\
\hline 2 & $\begin{array}{l}\text { dok anjing saya } \\
\text { mencret nya berbau dan } \\
\text { berdarah, lesy, dan }\end{array}$ & $\begin{array}{l}\text { - Diare Berdarah } \\
\text { - Lesu }\end{array}$ & Sesuai \\
\hline
\end{tabular}

Veronica Ambassador Flores: Aplikasi Sistem Pakar Diagnosa... 


\begin{tabular}{|c|c|c|c|}
\hline & tidak bersemangat & & \\
\hline 3 & $\begin{array}{l}\text { anjing saya golden usia } \\
5 \text { tahun, tidak mau } \\
\text { makan, badannya } \\
\text { panas, agak agresif dan } \\
\text { selalu sembunyi di } \\
\text { tempat gelap }\end{array}$ & $\begin{array}{l}\text { - Demam } \\
\text { - Kehilangan Nafsu } \\
\text { Makan } \\
\text { - Agresif }\end{array}$ & Sesuai \\
\hline 4 & $\begin{array}{l}\text { anjing saya } 2 \text { hari ini } \\
\text { aneh, sering mutah, } \\
\text { ketakutan, gak mau } \\
\text { makan, terus keluar } \\
\text { busa dari mulutnya }\end{array}$ & $\begin{array}{ll}\text { - } & \text { Muntah } \\
\text { - } & \text { Kehilangan Nafsu } \\
\text { Makan } \\
\text { - Air Liur yang } \\
\text { Berlebih }\end{array}$ & Sesuai \\
\hline 5 & $\begin{array}{l}\text { anjing saya masih usia } \\
2 \text { bulan, dia sering } \\
\text { bersin, dan hidungnya } \\
\text { meler terus, tidak } \\
\text { bersemangat, dan batuk }\end{array}$ & $\begin{array}{l}\text { - Hidung Berair } \\
\text { - Batuk } \\
\text { - Kulit Gatal } \\
\text { - Agresif } \\
\text { - } \text { Bulu Rontok } \\
\end{array}$ & $\begin{array}{l}\text { Tidak } \\
\text { Sesuai }\end{array}$ \\
\hline 6 & $\begin{array}{l}\text { anjing saya garuk2 } \\
\text { mulu, padahal gak ada } \\
\text { kutunya, sampai } \\
\text { kulitnya merah-merah }\end{array}$ & $\begin{array}{ll}\text { - } & \text { Kulit Gatal } \\
\text { - } & \text { Benjolan Merah } \\
\text { pada Kulit }\end{array}$ & Sesuai \\
\hline 7 & $\begin{array}{l}\text { dok mau tanya anjing } \\
\text { saya selalu lemas } \\
\text { badannya, air liurnya } \\
\text { juga menetes terus } \\
\text { seperti gejala rabies }\end{array}$ & $\begin{array}{l}\text { - } \text { Demam } \\
\text { - } \text { Air Liur yang } \\
\text { Berlebih } \\
\text { - Cemas } \\
\text { - Lemah }\end{array}$ & $\begin{array}{l}\text { Tidak } \\
\text { Sesuai }\end{array}$ \\
\hline 8 & $\begin{array}{l}\text { Urgent, anjing saya } \\
\text { badannya panas sekali, } \\
\text { sehari bisa } 5 x \text { muntah, } \\
\text { badannya lemes sekali } \\
\text { maunya tidur aja }\end{array}$ & $\begin{array}{l}\text { - Demam } \\
\text { - Muntah } \\
\text { - Lemah }\end{array}$ & Sesuai \\
\hline 9 & $\begin{array}{l}\text { doggy dirumah setiap } \\
\text { hari garuk2 sampai } \\
\text { bulunya rontoh, sudah } \\
\text { dikasi obat kutu tapi } \\
\text { tidak ada perubahan }\end{array}$ & $\begin{array}{l}\text { - } \text { Kulit Gatal } \\
\text { - } \text { Benjolan Merah } \\
\text { pada Kulit } \\
\text { - } \text { Bulu Rontok }\end{array}$ & Sesuai \\
\hline 10 & $\begin{array}{l}\text { kalau anjing saya sering } \\
\text { batuk-batuk dan } \\
\text { hidungnya bersin terus } \\
\text { artinya apa ya ? flu } \\
\text { kah? }\end{array}$ & $\begin{array}{l}\text { - Hidung Berair } \\
\text { - Batuk }\end{array}$ & Sesuai \\
\hline
\end{tabular}

Tabel 8 menunjukkan bahwa metode $N$-gram dapat mengenali pola dengan baik sesuai dengan pesan yang dikirimkan oleh pengguna. Pola dengan kesalahan ketik pun tetap dapat dikenali dengan baik. Tabel 7 menampilkan data keluhan pengguna mengenai penyakit yang dialami oleh anjing peliharaan mereka, dari 10 pesan pengguna, sistem dapat mengenali 8 pola dengan tepat sesuai dengan pesan dari pengguna, 2 pesan lainnya tetap dapat dikenali polanya namun sistem juga mendeteksi adanya pola lain yang dianggap cocok. Keberhasilan dalam mengenali pola tergantung dengan proses text pre-processing yang sebelumnya sudah dilewati, proses ini mebantu sistem untuk mengenali sebuah pola secara lebih akurat. Faktor utama dari keberhasilan dalam mengenali pola yaitu tergantung dengan padanan pola yang di daftarkan, faktor lainnya yaitu pembuangan kata-kata yang dianggap sebagai stopword, agar sistem tidak harus melakukan pencocokan dengan kata lain diluar pola gejala yang dicari.

\section{Akurasi Klasifikasi Penyakit}

Veronica Ambassador Flores: Aplikasi Sistem Pakar Diagnosa...

Metode yang digunakan dalam melakukan klasifikasi yaitu Template Matching, dimana pola gejala yang di dapat dari pesan pengguna diubah kedalam bentuk biner dan dicocokkan dengan template pola penyakit.

TABEL 9

UJI COBA KLASIFIKASI PENYAKIT

\begin{tabular}{|c|c|c|c|}
\hline No & Identifikasi Pola & Diagnosa Penyakit & Hasil \\
\hline 1 & 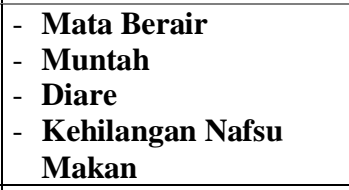 & $\begin{array}{l}\text { Canine Distemper } \\
\text { (Virus Distemper) }\end{array}$ & Sesuai \\
\hline 2 & $\begin{array}{l}\text { - Diare Berdarah } \\
\text { - Lesu }\end{array}$ & 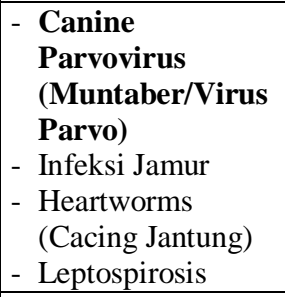 & $\begin{array}{l}\text { Tidak } \\
\text { Sesuai }\end{array}$ \\
\hline 3 & $\begin{array}{l}\text { - Demam } \\
\text { - } \text { Kehilangan Nafsu } \\
\text { Makan } \\
\text { - Agresif }\end{array}$ & Rabies & Sesuai \\
\hline 4 & $\begin{array}{l}\text { - } \text { Muntah } \\
\text { - } \text { Kehilangan Nafsu } \\
\text { Makan } \\
\text { - Air Liur yang } \\
\text { Berlebih } \\
\end{array}$ & $\begin{array}{l}\text { - Canine Parvovirus } \\
\text { (Muntaber/Virus } \\
\text { Parvo) } \\
\text { - Rabies }\end{array}$ & $\begin{array}{l}\text { Tidak } \\
\text { Sesuai }\end{array}$ \\
\hline 5 & $\begin{array}{l}\text { - Hidung Berair } \\
\text { - Batuk } \\
\text { - Kulit Gatal } \\
\text { - Agresif } \\
\text { - Bulu Rontok }\end{array}$ & $\begin{array}{l}\text { - Canine Distemper } \\
\text { (Virus Distemper) } \\
\text { - Canine Influenza } \\
\text { (Flu) } \\
\text { - Kennel Cough } \\
\text { (Batuk) } \\
\text { - Ringworm (Jamur } \\
\text { Kulit) }\end{array}$ & $\begin{array}{l}\text { Tidak } \\
\text { Sesuai }\end{array}$ \\
\hline 6 & $\begin{array}{l}\text { - Kulit Gatal } \\
\text { - Benjolan Merah pada } \\
\text { Kulit }\end{array}$ & $\begin{array}{l}\text { Parasit (kutu dan } \\
\text { kudis) }\end{array}$ & Sesuai \\
\hline 7 & $\begin{array}{l}\text { - Demam } \\
\text { - Air Liur yang } \\
\text { Berlebih } \\
\text { - Cemas } \\
\text { - } \text { Lemah } \\
\end{array}$ & $\begin{array}{l}\text { - Heatstroke } \\
\text { (Kepanasan) } \\
\text { - Rabies }\end{array}$ & Sesuai \\
\hline 8 & $\begin{array}{l}\text { - Demam } \\
\text { - Muntah } \\
\text { - Lemah } \\
\end{array}$ & Leptospirosis & Sesuai \\
\hline No & Identifikasi Pola & Diagnosa Penyakit & Hasil \\
\hline 9 & $\begin{array}{ll}\text { - } & \text { Kulit Gatal } \\
\text { - } & \text { Benjolan Merah pada } \\
& \text { Kulit } \\
\text { - } & \text { Bulu Rontok } \\
\end{array}$ & $\begin{array}{l}\text { - Parasit (kutu dan } \\
\text { kudis) } \\
\text { - Ringworm } \\
\text { (Jamur Kulit) }\end{array}$ & Sesuai \\
\hline 10 & $\begin{array}{l}\text { - Hidung Berair } \\
\text { - Batuk }\end{array}$ & $\begin{array}{l}\text { - Canine Distemper } \\
\text { (Virus Distemper) } \\
\text { - Canine Influenza } \\
\text { (Flu) } \\
\text { - Kennel Cough } \\
\text { (Batuk) }\end{array}$ & $\begin{array}{l}\text { Tidak } \\
\text { Sesuai }\end{array}$ \\
\hline
\end{tabular}

Tabel 9 menunjukkan diagnosa penyakit yang dapat dikenali berdasarkan gejala yang diberikan dari hasil 
identifikasi pola pada Tabel 8 , dari 10 data pola gejala terdapat 8 data yang dapat di diagnosa dengan benar, 2 data gejala lainnya di diagnosa dengan hasil yang tepat diiringi dengan hasil diagnosa lainnya dengan gejala yang mirip.

\section{KESIMPULAN}

Berdasarkan penelitian dari Aplikasi Sistem Pakar Diagnosa Penyakit anjing Berbasis Facebook Messenger dapat disimpulkan bahwa :

1. Aplikasi Sistem Pakar Diagnosa Penyakit anjing bekerja dengan memproses masukan dari pengguna dengan memanfaatkan metode Natural Language Processing.

2. Aplikasi dapat mengidentifikasi pola gejala sesuai dengan yang dikirimkan pengguna menggunakan metode $N$-gram dengan tingkat akurasi sebesar $80 \%$. Berdasarkan hasil ujicoba dari 10 data, terdapat 8 data yang dapat dikenali gejalanya dengan baik.

3. Aplikasi dapat melakukan klasifikasi penyakit berdasarkan pola gejala yang telah dikenali sebelumnya menggunakan metode Template Matching. Metode Template Matching dapat digunakan sebagai metode diagnosa penyakit berdasarkan kumpulan template pola yang telah didaftarkan. Metode ini dapat bekerja dengan baik dalam mendiagnosa penyakit anjing dengan akurasi sebesar $80 \%$, dimana dari total 10 data gejala, sistem dapat mendiagnosa 8 data gejala diantaranya dengan tepat.

4. Aplikasi ini memanfaatkan interface Facebook Messenger agar pengguna awam dapat lebih mudah untuk berinteraksi, dilengkapi dengan Natural Language Processing (NLP) membuat pengguna dapat berkirim pesan menggunakan bahasa sehari-hari. Metode $N$-gram juga mendukung sistem agar tetap dapat mengenali pola yang memiliki kesahalan ketik.

5. Berdasarkan tingkat akurasi dari hasil ujicoba yang telah dilakukan, Aplikasi Sistem Pakar Diagnosa Penyakit anjing Berbasis Facebook Messenger dapat digunakan untuk memberikan hasil diagnosa awal beserta deskripsi dari penyakit tersebut.

\section{REFERENSI}

[1] T. Rahmah, T. R. Ferasyi, Razali, M. Hambal, Rastina and Rusli, "Estimation of Dog Population and Owner Knowledge Toward Rabies Risk of Dog in Padang Ganting Sub-district," Jurnal Medika Veterinaria, vol. 11, no. 1, 2017.

[2] C. K. Kramer, S. Mehmood and R. S. Suen, "Dog Ownership and Survival : A Systematic Review and Meta-Analysis," Circulation: Cardiovascular Quality and Outcomes, vol. 12, no. 10, 2019.

[3] C. Amiot, B. Bastian and P. Martens, "People and Companion Animals: It Takes Two to Tango," BioScience, vol. 66, no. 7, 2016.

[4] Y. L. X. G. S. G. Tailai Wu, "A Study of Active Usage of Mobile Instant Messaging Application: An attachment theory perspective," Information Development, vol. 33, no. 2, 2016.

[5] A. P. J. I. Indonesia, "Penetrasi \& Profil Pengguna Internet Indonesia 2018," Asosiasi Penyelenggara Jasa Internet Indonesia, Indonesia, 2018.

[6] M. A. Ali, "Artificial intelligence and natural language processing: the Arabic corpora in online translation software," International Journal of Advanced and Applied Sciences, vol. 3, no. 9, 2016.

[7] B. Zaman, E. Hariyanti and E. Purwanti, "Sistem Deteksi Bahasa pada Dokumen menggunakan N-Gram," Jurnal Multinetics, vol. 1, no. 2, 2015.

[8] I. F. Katili and F. D. Esabella, "Pattern Recognition Of Javanese Letter
Using Template Matching Correlation Method," Journal of Applied Intelligent System, vol. 3, no. 2, 2018.

[9] A. Wrzalik and B. Jereb, “ Use Of Expert Systems In Crisis Management," Czoto, vol. 1, no. 1, 2019.

[10] A. M. Karim, F. V. Çelebi and A. S. Mohammed, "Software Development for Blood Disease Expert System," Lecture Notes on Software Engineering, vol. 4, no. 3, 2016.

[11] D. Agustina, H. Mustafidah and M. R. Purbowati, "Sistem Pakar Diagnosa Penyakit Kulit Akibat Infeksi Jamur,” JUITA, vol. 4, no. 2, 2016.

[12] S. R. Joseph, H. Hlomani and K. Letsholo, "Natural Language Processing: A Review," International Journal of Research in Engineering and Applied Sciences, vol. 6, no. 3, 2016.

[13] B. Zaman, E. Hariyanti and E. Purwanti, "Sistem Deteksi Bahasa pada Dokumen menggunakan N-Gram,” JURNAL MULTINETICS, vol. 1, no. 2,2015

[14] N. T. X. Huong, T.-T. Dang, T.-T. Nguyen and Anh-Cuong, "Using Large N-gram for Vietnamese Spell Checking," Advances in Intelligent Systems and Computing, vol. 326, 2015.

[15] C. F. Tan, L. S. Wahidin, S. N. Khalil, N. Tamaldin, J. Hu and G. M. Rauterberg, "The application of expert system: A review of research and applications," ARPN Journal of Engineering and Applied Sciences, vol. 11, no. 4, 2016.

[16] P. C. Munaiseche, D. R. Kaparang and P. T. D. Rompas, "An Expert System for Diagnosing Eye Diseases using Forward Chaining Method," IOP Conference Series: Materials Science and Engineering, vol. 306, no. $1,2018$.

[17] N. L. Ratniasih, M. Sudarma and N. Gunantara, “ Penerapan Text Mining dalam Spam Filtering untuk Aplikasi Chat," Majalah Ilmiah Teknologi Elektro, vol. 16, no. 3, 2017.

[18] N. G. Yudiarta, M. Sudarma and W. G. Ariastina, "Penerapan Metode Clustering Text Mining Untuk Pengelompokan Berita Pada Unstructured Textual Data,” Majalah Ilmiah Teknologi Elektro, vol. 17, no. 3, 2018.

[19] M. S. N. P. Dewa Ayu Putri Wulandari, "Pemanfaatan Big Data Media Sosial Dalam Menganalisa Kemenangan Pilkada," Majalah Ilmiah Teknologi Elektro, vol. 18, no. 1, 2019.

[20] I. Pujadayanti, M. A. Fauzi and Y. A. Sari, "Prediksi Rating Otomatis pada Ulasan Produk Kecantikan dengan Metode Naïve Bayes dan Ngram,” Jurnal Telematika, vol. 2, no. 11, 2018.

[21] Badrinaathan.J and L.N.B.Srinivas, "Angle and Scale Invariant Template Matching for Handling Image Distortions," International Journal of Engineering \& Technology, vol. 7, no. 2, 2018.

[22] I. M. O. Widyantara, A. T. A. P. Kusuma and N. M. A. E. D. Wirastuti, "Preprocessing pada Segmentasi Citra Paru-Paru dan Jantung Menggunakan Anisotropic Diffusion Filter," Majalah Ilmiah Teknologi Elektro, vol. 14, no. 2, 2015.

[23] K. O. Oseni, K. Dingley and P. Hart, "Instant Messaging and Social Networks - The Advantages in Online Research Methodology," International Journal of Information and Education Technology, vol. 8, no. 1, 2018.

[24] A. Yudhana, b. Riadi and c. Anshori, "Identification of Digital Evidence Facebook Messenger on Mobile Phone With National Institute of Standards Technology (NIST) Method,” Jurnal Ilmiah KURSOR, vol. 9, no. 3, 2018.

[25] P. S. M. Suryani, L. Linawati and K. O. Saputra, "Penggunaan Metode Naïve Bayes Classifier pada Analisis Sentimen Facebook Berbahasa Indonesia,” Majalah Ilmiah Teknologi Elektro, vol. 18, no. 1, 2019.

[26] A. V. M. Association, "Disease Risks for Dogs in Social Settings," 29 Oktober 2019. [Online]. Available: https://www.avma.org/public/PetCare/Pages/Disease-Risks-forDogs.aspx. 